\title{
Performance Evaluation of Animal Drawn Single Row Maize Ridger
}

\author{
Manish Kumar*, Parmanand Sahu and R. K. Naik \\ Department of Farm Machinery and Power Engineering, SVCAET \& RC, \\ Faculty of Agricultural Engineering, Indira Gandhi Krishi Vishwavidyalaya, \\ Raipur- 492006 (C.G.) India \\ *Corresponding author
}

\section{A B S T R A C T}

\begin{tabular}{|l|}
\hline K e y w o r d s \\
Maize, ridger, \\
animal power, cost \\
economics, ridge \\
planting
\end{tabular}

In the present study, the performance evaluation of developed animal drawn single row maize ridger was observed. The field capacity $(0.059 \mathrm{ha} / \mathrm{h})$, field efficiency $(74.74 \%)$ with less plant damage $(2.92 \%)$ and highest weeding efficiency $(46.18 \%)$ and ridge dimensions bottom width, top width, ridge height $(43.75 \mathrm{~cm}, 12.75,16 \mathrm{~cm})$. The developed maize ridger was observed an average draft of about $69.81 \mathrm{~kg}-\mathrm{f}$ with an average power requirement $0.491 \mathrm{hp}$. Average speed of ridging operation was observed $1.74 \mathrm{~km} / \mathrm{h}$. The performance of maize ridger compared with Ridger plough, Tendua plough and MB Plough. The effective field capacity of developed maize ridger was found higher $(0.0548$ $\mathrm{ha} / \mathrm{h})$ followed by Tendua plough $(0.0395 \mathrm{ha} / \mathrm{h})$, ridger plough $(0.0360 \mathrm{ha} / \mathrm{h}), \mathrm{MB}$ plough $(0.0158 \mathrm{ha} / \mathrm{h})$.and volume of soil handled were found highest with ridger plough $(492.38$ $\left.\mathrm{cm}^{3}\right)$ followed by developed maize ridger $\left(452.31 \mathrm{~cm}^{3}\right), \mathrm{MB}$ plough $\left(305.38 \mathrm{~cm}^{3}\right)$ and minimum with Tendua plough $\left(148.36 \mathrm{~cm}^{3}\right)$ the total cost of operation was found minimum with developed maize ridger (1737.79 Rs/ha) followed by Tendua plough (2652.82 Rs/ha), Ridger plough (3000.00 Rs/ha) and maximum with MB plough (6440.00 $\mathrm{Rs} / \mathrm{ha})$.

\section{Introduction}

In India, the production of maize witnessed a significant increase of more than 14 times from a mere 1.73 million tons in $1950-51$ to 28.72 million tons in 2017-18. Presently it occupies 9.23 million hectare area with the mean yield of 2.56 tons/hectare. In Chhattisgarh, maize is a kharif season crop and second most important crop next to paddy in terms of both area and production. In Chhattisgarh maize occupies 119.63 thousands hectare land with the productivity of $2566 \mathrm{Kg} / \mathrm{ha}$ in Kharif 2017. Maize can be grown successfully in variety of soils ranging from loamy sand to clay loam.

However, soils with good organic matter content having high water holding capacity with neutral $\mathrm{pH}$ are considered good for higher productivity. The state has got very good potential for maize but the productivity is very low due to improper input management practices [1]. 
Crop cultivation in India requires application of both animate (bullock, human power) and inanimate (tractors, tillers etc.) forms of energy at different stages. The bullocks and buffaloes are the main stay of farm power in India and they still command over $60 \%$ of the total cultivable land. About $90 \%$ of the tillage operation in India is still carried out by the draught animals [2]. The bullocks and buffaloes are the main stay of farm power in India and they still command over $60 \%$ of the total cultivable land. More than $55 \%$ of the total cultivated area is still being managed by using draught animals as against about $20 \%$ by tractors [3]. The marginal farmers who constitute $80 \%$ of the total farming community of the country with low purchasing capacity extensively depend on draught animal power for different agricultural operations.

Today animal traction farmers faces many constraints like high draught, poor design of harnesses, forces rapid ploughshare wear, and many other implements [4]. At the same time shortage of agricultural labours due to rapid urbanization is a constraint in crop production. In this context there is a huge scope for introduction of various matching bullock drawn implements in various agricultural operations. Generally the raised bed planting is considered as best planting method for maize during monsoon and winter seasons both under excess moisture as well as limited water availability/rained conditions. Sowing/planting should be done on the southern side of the east-west ridges/beds, which helps in good germination. Planting should be done at proper spacing. Recently in Chhattisgarh maize planting is done by manually by line sowing method but due to unavailability of proper ridging/ earthening equipments the farmers have to make ridge by traditional method, which is laborious. The labour availability is scare during the earthening period in kharif and rabi season.
The cost of production is also increases due to the manual labor.

In maize the weed control and plant growth can be increased by the adoption of ridge planting. The ridge plant system is well suited to furrow- irrigated crops. Sometimes due to excessive rain in the crop may be damage due to water logging. To make favourable condition the ridge and furrow were provided to drain out excessive water. It also provides better root growth due to proper aeration in root zone. Due to ridge farming the bulk density may improve which consequently improve the water and nutrient intake in the plants. It is well known fact that improved tillage and proper management practice reduces weed growth and enhance crop production. A proper ridging method is still not available for animal drown farming system. In Chhattisgarh still the ridge preparation is perform either by manual or animal drawn method which is slow, time consuming and tedious in nature.

In Chhattisgarh ridge preparation for maize crop performed by the traditional method by either by manual by the help of Khurpi or desi/country plough pulled by a man or by a pair of skilled bullock. Traditional method of earthening/ridging adopted in maize cultivation is slow, time consuming, tedious, inefficient and involve drudgery, hence increases the cost of production. Looking to the above points and to reduce drudgery in the earthening operation development of a suitable animal drawn ridger is essential for reducing cost of operation of maize.

The main objectives of the present study include to study the performance of the developed animal drawn single row maize ridger. And also to workout the cost economics of the developed animal drawn single row maize ridger. 


\section{Materials and Methods}

Field performance tests were carried out to obtain actual data on overall implement performance and work capacity in the field. The field trials of animal drawn implements were conducted in the field of I.G.K.V., Raipur.

\section{Field performance parameter}

The following observations were taken during the field test.

Plant height, Moisture content of the soil, Bulk density of soil, Mean Mass Diameter (MMD), Measurement of draft, Speed of operation, Power requirement, Field capacity (Theoretical field capacity, Effective field capacity), Field efficiency, Soil inversion and Plant damaged/injured.

\section{Moisture content of the soil}

The moisture content was determined using the relation.

$M c=\frac{W_{w}-W_{d}}{W_{d}}$

Where,

$\mathrm{M}_{\mathrm{c}}=$ Moisture content of soil, $\% \mathrm{db}$;

$\mathrm{W}_{\mathrm{w}}=$ Weight of wet soil, $\mathrm{g}$; and

$\mathrm{W}_{\mathrm{d}}=$ Weight of oven dry soil, $\mathrm{g}$.

\section{Bulk density}

The bulk density was calculated by using formula

$\delta=\frac{M}{V}$

Where, $\delta=$ bulk density of soil, $\mathrm{g} / \mathrm{cm}^{3}$;

$\mathrm{M}=$ oven dry mass of soil, $\mathrm{g}$; and
$\mathrm{V}=$ volume of core sampler, $\mathrm{cm}^{3}$.

\section{Mean mass diameter (MMD)}

The following expression was used to calculate Mean Mass Diameter (MMD)

MMD

$=\left(\sum\left(\mathrm{M}(\mathrm{I}) \times\left(\mathrm{D}(\mathrm{I}-1)+\mathrm{D}(\mathrm{I}) / 2 / \sum \mathrm{M}(\mathrm{I})\right.\right.\right.$

$=[\{\mathrm{M}(1) \times \mathrm{D}(0)+\mathrm{D}(1)\} / 2+\{\mathrm{M}(2) \times \mathrm{D}$

(1) $\mathrm{D}(2)\} / 2+\ldots \ldots.] /[\mathrm{M}(1)+\mathrm{M}(2)+\ldots \ldots$.

Where,

$M(I)=$ mass of the soil retained on $\mathrm{I}^{\mathrm{st}}$ sieve from top, $\mathrm{kg}$;

$\mathrm{D}(\mathrm{I})=$ size of the $1^{\text {st }}$ sieve, $\mathrm{mm}$; and

$\mathrm{D}(0)=$ size (second major dimension) of the largest clod on top sieve, $\mathrm{mm}$.

\section{Measurement of draft}

The draft was calculated as follows.

$$
\begin{aligned}
& \mathrm{H}=\sqrt{\mathrm{B}^{2}-[(\mathrm{V}-\mathrm{H})]^{2}} \\
& \mathrm{H}=\frac{\mathrm{V}-\mathrm{h}}{\operatorname{Tan} \theta}
\end{aligned}
$$

$\theta=\operatorname{Tan}^{-1} \frac{\mathrm{V}-\mathrm{h}}{\mathrm{H}}$

Where,

$\theta \quad=\quad$ Angle of pull

$\mathrm{h}=$ Height of hitch of implement from ground

$\mathrm{B}=$ Length of beam up-to yoke

$\mathrm{H}=$ Horizontal distance between hitch point and the neck of the bullock

$\mathrm{V}=$ Vertical height of the up-to neck of bullock from ground

$\mathrm{D}=\mathrm{P} \cdot \cos \theta$ 
Where,

$\mathrm{D}=$ draft, kgf.

$\mathrm{P} \quad=\quad$ pull (dynamometer reading),

$\mathrm{kg}$. $\quad$ Angle between the line of pull

$\theta \quad=\quad$ Angle between the line of pull and horizontal, degree.

\section{Speed of operation}

Speed $(\mathrm{kmph})=\frac{3.6 \mathrm{X} \text { distance travelled }(\mathrm{m})}{\text { time }(\mathrm{s})}$

\section{Power requirement}

Calculation of power is needed to determine the efficient use of animal power. A bullock can produce power equal to 0.5 to $0.75 \mathrm{hp}$ operated for day long work. It was the power required to the implement by the bullock with average pulling force and speed. It was calculated by using the following formula (Michael and Ojha, 1966).

H. P. $=\frac{\text { Draft }(\mathrm{kg}) \times \text { distance moved }(\mathrm{m} / \mathrm{s})}{75}$

\section{Theoretical field capacity}

It is the rate of field coverage that would be obtained if implements were performing its function $100 \%$ of the time at the rated speed and always covering $100 \%$ of its rated width.

$\mathrm{TFC}=\frac{\mathrm{W} \times \mathrm{S}}{10}$

Where,

TFC = Theoretical Field Capacity, ha/h;

$\mathrm{S} \quad=$ Speed of Operation, $\mathrm{km} / \mathrm{h}$; and

$\mathrm{W}=$ Theoretical width of implement, $\mathrm{m}$

\section{Effective field capacity}

It is the actual average rate of coverage by the implement. The total time required to complete the operation was recorded and effective field capacity was calculated as follows.

$\mathrm{EFC}=\frac{\mathrm{A}}{\mathrm{T}}$

Where,

$\mathrm{EFC}=$ Effective field capacity, ha/h;

$\mathrm{A}=$ Actual area covered, ha; and

$\mathrm{T}=$ Total time required to cover the area, $h$.

\section{Field efficiency}

It was calculated by using the following formula

Field efficiency $=\frac{\text { Effective field capacity }}{\text { Theoretical field capacity }} \times 100$

\section{Results and Discussion}

As per objectives, the experiment was conducted on the research fields of I.G.K.V., Raipur and data were statistically analyzed. Based on the experimental findings, the frame having adjustable furrow spacing was designed and developed, which was further evaluated with the traditional method.

The developed ridging implement consists of frame, handle, share, mould board, frog, landside, hitch and beam. The construction of the implement was studied and matching to the pulling capacity of the local bullocks.

From the test result which was revealed from Table: 1 it was observed that the highest volume of soil handled was observed with T4 - ridger plough $\left(492.38 \mathrm{~cm}^{3}\right)$ followed by T3 - developed maize ridger $\left(452.31 \mathrm{~cm}^{3}\right)$, T2 MB plough $\left(305.38 \mathrm{~cm}^{3}\right)$ and $\mathrm{T} 1$ - Tendua plough $\left(148.36 \mathrm{~cm}^{3}\right)$. From the above results, it was revealed that the ridge dimensions and volume of soil handled by ridger plough and developed maize ridger was at par. 
Table.1 Effect of different ridging technology on dimension of the ridge and volume of soil cut

\begin{tabular}{|l|c|c|c|r|}
\hline \multirow{2}{*}{$\begin{array}{l}\text { Parameters/ } \\
\text { Treatments }\end{array}$} & \multicolumn{3}{|c|}{ Dimension of ridge } & \multirow{2}{*}{ Volume, $\mathbf{c m}^{3}$} \\
\cline { 1 - 4 } T1 & Bottom width, cm & Top width, cm & Height, cm & \\
\hline T2 & 59.93 & 53.00 & 2.63 & 148.36 \\
\hline T3 & 41.75 & 15.00 & 10.75 & 305.38 \\
\hline T4 & 43.75 & 12.75 & 16.00 & $452.31 *$ \\
\hline SEm & 55.00 & 5.75 & 16.25 & $492.38^{*}$ \\
\hline CD at 5\% & 0.468 & 0.692 & 1.140 & 34.871 \\
\hline CV & 1.496 & 2.214 & 3.646 & 111.552 \\
\hline
\end{tabular}

T1 (Tendua plough), T2 (MB plough), T3 (Developed maize ridger) and T4 (Ridger plough)

Table.2 Effect of different ridging technology on speed, draft, TFC, EFC, FE plant damage and weeding efficiency

\begin{tabular}{|l|l|l|c|c|c|c|r|}
\hline $\begin{array}{l}\text { Parameters/ } \\
\text { Treatments }\end{array}$ & $\begin{array}{l}\text { Speed } \\
(\mathbf{k m} / \mathbf{h})\end{array}$ & $\begin{array}{l}\text { Draft } \\
\mathbf{( k g} \mathbf{f})\end{array}$ & $\begin{array}{c}\text { TFC } \\
\mathbf{( h a / h )}\end{array}$ & $\begin{array}{c}\text { EFC } \\
\mathbf{( h a / h )}\end{array}$ & $\begin{array}{c}\text { FE } \\
\mathbf{( \% )}\end{array}$ & $\begin{array}{r}\text { Plant } \\
\text { Damage } \\
(\mathbf{\%})\end{array}$ & $\begin{array}{r}\text { Weeding } \\
\text { efficiency } \\
(\mathbf{\%})\end{array}$ \\
\hline T1 & 1.86 & 32.25 & 0.0537 & 0.0395 & $73.68^{\mathrm{a}}$ & $1.21^{*}$ & 13.00 \\
\hline T2 & 1.44 & 72.25 & 0.0287 & 0.0158 & $54.65^{\mathrm{b}}$ & 10.48 & 59.25 \\
\hline T3 & 1.73 & 69.50 & 0.0733 & 0.0548 & $74.62^{\mathrm{a}}$ & $2.02^{*}$ & 51.50 \\
\hline T4 & 1.30 & 76.75 & 0.0698 & 0.0360 & $51.62^{\mathrm{b}}$ & 27.42 & 68.25 \\
\hline SEm & 0.043 & 1.231 & 0.002 & 0.002 & 2.237 & 0.902 & 1.900 \\
\hline CD at 5\% & 0.136 & 3.938 & 0.006 & 0.006 & 7.156 & 2.884 & 6.079 \\
\hline CV & 5.387 & 3.928 & 6.410 & 10.128 & 7.030 & 17.538 & 7.918 \\
\hline
\end{tabular}

T1 (Tendua plough), T2 (MB plough), T3 (Developed maize ridger) and T4 (Ridger plough)

Table.3 Calculation of cost of different ridging technology

\begin{tabular}{|c|c|c|c|c|c|}
\hline S. No. & Particular & $\begin{array}{l}\text { Developed } \\
\text { maize ridger }\end{array}$ & $\begin{array}{l}\text { Ridger } \\
\text { plough }\end{array}$ & $\begin{array}{l}\text { Tendua } \\
\text { plough }\end{array}$ & MB plough \\
\hline 1. & Cost of machine, Rs & 2960.00 & 7500.00 & 2400.00 & 2850.00 \\
\hline 2. & Life of the machine (year) & 5 & 10 & 5 & 10 \\
\hline 3. & Annual use (h) & 240 & 240 & 240 & 240 \\
\hline 4. & Depreciation, Rs/year @ 10\% & 532.80 & 675.00 & 432.00 & 256.50 \\
\hline 5. & Interest, Rs/year@12\% & 195.36 & 495.00 & 158.40 & 188.10 \\
\hline Total $(4+5)$ & Fixed cost (Rs/Year) annual use is $240 \mathrm{~h}$ & 728.16 & 1170.00 & 590.40 & 444.60 \\
\hline A & Fixed cost $(\mathrm{Rs} / \mathrm{h})$ & 3.03 & 4.88 & 2.46 & 1.85 \\
\hline B & Operational cost & & & & \\
\hline 1. & Wage of 1 operator (Rs 200/day*), Rs/h & 25 & 25 & 25 & 25 \\
\hline 2. & $\begin{array}{l}\text { Hiring charges of bullock (300/day*), } \\
\text { Rs/h }\end{array}$ & 75 & 75 & 75 & 75 \\
\hline 3. & Repair and maintenance, $\mathrm{Rs} / \mathrm{h}$ & 1.23 & 4.17 & 1.00 & 1.19 \\
\hline$\Sigma(1$ to3 $)$ & Total operational cost, Rs/h & 101.23 & 104.17 & 101.00 & 101.19 \\
\hline$(A+B)$ & Machinery cost, (Rs/h) & 104.27 & 108.00 & 103.46 & 103.04 \\
\hline & Machine capacity & 0.06 & 0.04 & 0.04 & 0.02 \\
\hline \multicolumn{2}{|c|}{ Total machinery cost in, (Rs/ ha) } & 1737.79 & 3000.00 & 2652.82 & 6440.00 \\
\hline
\end{tabular}

*1 day i.e. 8 hour of work 


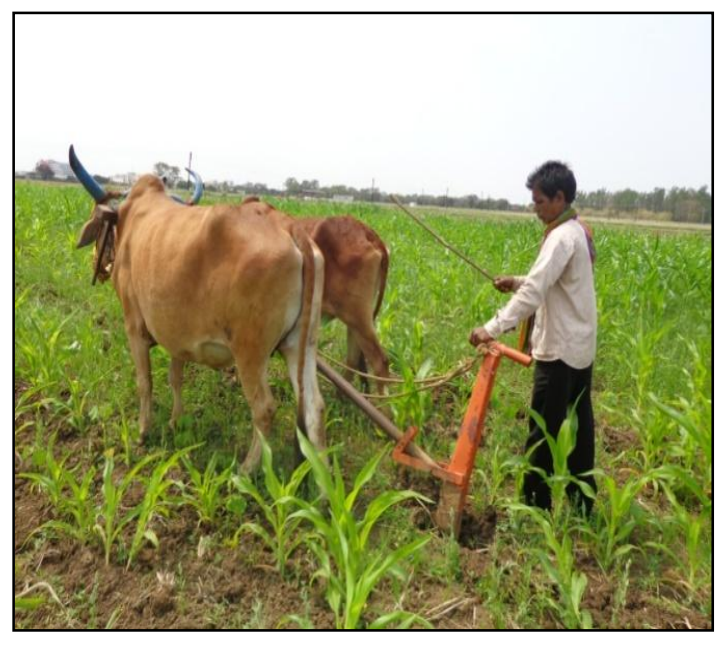

Fig.1 Ridging with tendua plough

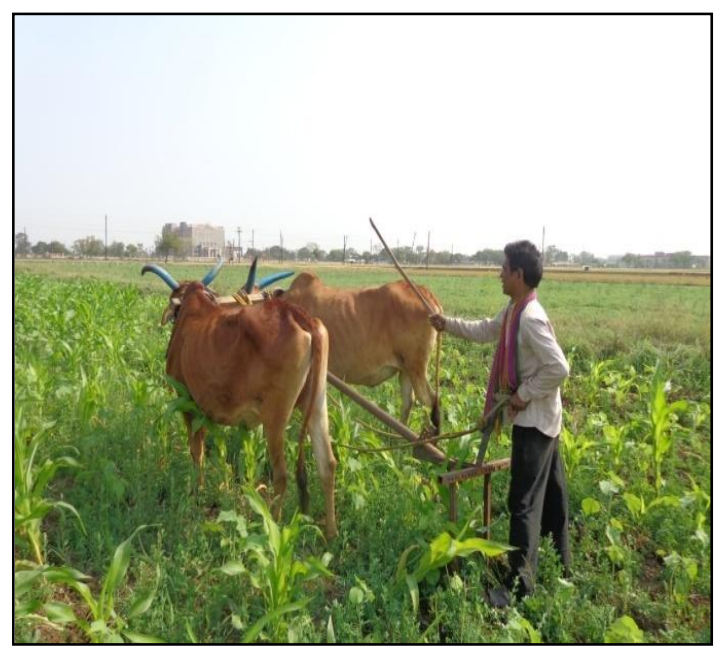

Fig.3 Ridging with developed Rodger

The Table:2 shows that the lower plant damage were obtained with T1-Tendua plough $(1.21 \%)$ followed by T3- developed maize ridger $(2.02 \%)$, T2- MB plough $(10.48 \%)$ and higher plant damage was observed with T4- ridger plough (27.42\%). The plant damage with Tendua plough and developed maize ridger was at par. The maximum weeding efficiency was observed with T4- ridger plough $(68.25 \%)$ followed by T2- MB plough (59.25\%), T3- developed maize ridger $(51.50 \%)$ and lowest weeding efficiency was observed with T1- Tendua

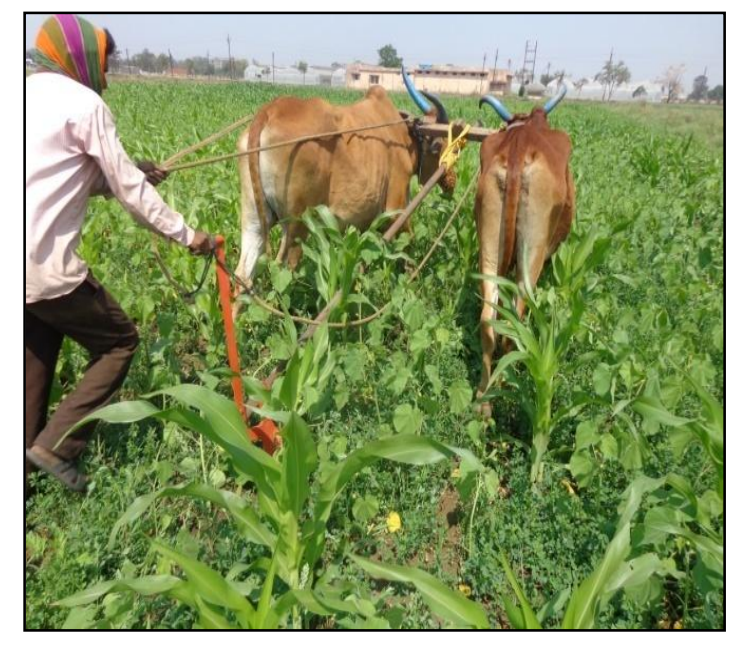

Fig.2 Ridging with MB plough

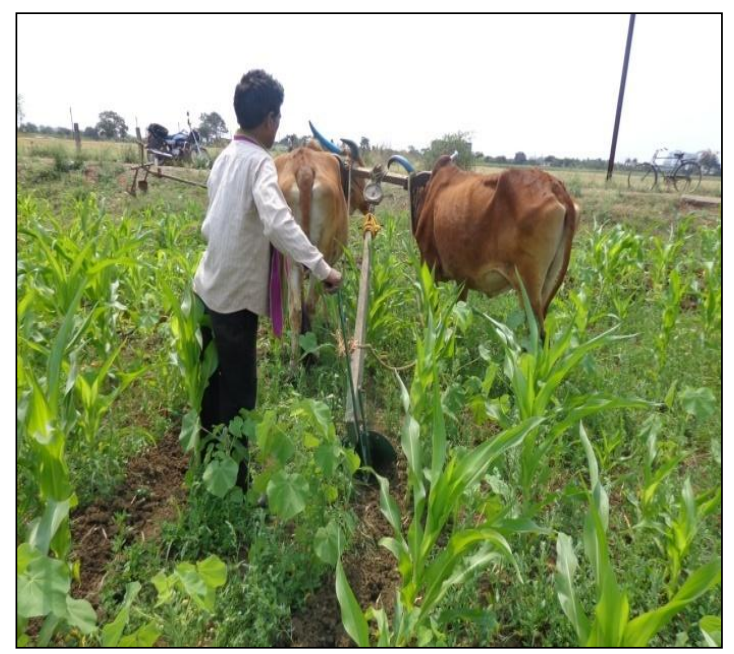

Fig.4 Ridging with ridger plough

plough (13\%).

The weeding efficiency of ridger plough, MB plough and developed maize were found at par.

\section{Cost economics}

The cost of operation of the implement per hour as well as per ha is presented in Table 3. The annual use of the machine was taken only 240 hour per year. The estimated data revels that the cost of operation of the implement mainly depends upon its EFC. In present 
assumption the fixed cost was found to be Rs.3.03, operational cost as Rs 101.24 per hour for the developed ridger which was nearer to the other methods of ridging technology. But due to field capacity the cost of operation (Rs 1737.79) with the developed ridger was found lowest among all other techniques.

\section{References}

1. S. K. Sinha, A. K. Sinha, D. Thakur, A. Lakra, and A. K. Tripathi, "Maize Research in Chhattisgarh: Status and Progress," Int. J. Curr. Microbiol. Appl. Sci., vol. 8, no. 3, pp. 2210-2230, 2019.

2. P. Priyadarsini Jena and S. Khandai, "Performance Evaluation of Bullock Drawn Three-Row Inclined Plate Planter," Int. J. Curr. Microbiol. Appl. Sci., vol. 6, no. 11, pp. 1545-1553, 2017.

3. G. Singh, "Draught animal energy research in India," no. September, pp. 315-322, 1999.

4. K. K. Panigrahy, S. Panda, and S. K. Gupta, "Care and Management of Drought Animals: a Review," vol. 5, no. 5, pp. 3339-3345, 2016.

5. J. Sahay," Element of Agricultural Engineering", Standard publishers Distributers1705, Nai Sarak, Delhi110006, pp 160-161, 2008 https://agriportal.cg.nic.in/agridept/AgriEn /KHARIF_17

6. Annon., 2018. Agriculture Statistics at a Glance 2018. Govt. of India Ministry of Agriculture and Farmers Welfare Directorate of Economics and Statistics.

7. https://www.farmer.gov.in/image default /pest and diseasecrops/ normalmaize production technologies.pdf

8. Devnani, R.S. (1991) Agricultural Machinery design and data hand book RNAM ESCAP.

\section{How to cite this article:}

Manish Kumar, Parmanand Sahu and Naik. R. K. 2020. Performance Evaluation of Animal Drawn Single Row Maize Ridger. Int.J.Curr.Microbiol.App.Sci. 9(06): 24-30.

doi: https://doi.org/10.20546/ijcmas.2020.906.003 